\title{
Body Temperature and Thermal Environment in a Generalized Arboreal Anthropoid, Wild Mantled Howling Monkeys (Alouatta palliata)
}

\author{
Cynthia L. Thompson, ${ }^{1 *}$ Susan H. Williams, ${ }^{2}$ Kenneth E. Glander, ${ }^{3}$ Mark F. Teaford, ${ }^{4}$ \\ and Christopher J. Vinyard ${ }^{5}$ \\ ${ }^{1}$ Department of Biomedical Sciences, Grand Valley State University, Allendale, MI \\ ${ }^{2}$ Department of Biomedical Sciences, Ohio University Heritage College of Osteopathic Medicine, Athens, OH \\ ${ }^{3}$ Department of Evolutionary Anthropology, Duke University, Durham, NC \\ ${ }^{4}$ Department of Physical Therapy, School of Health Sciences, High Point University, High Point, NC \\ ${ }^{5}$ Department of Anatomy and Neurobiology, Northeast Ohio Medical University, Rootstown, $\mathrm{OH}$
}

KEY WORDS thermoregulation; heat stress; cold stress; human adaptations; tempera-

ture variability

\begin{abstract}
Free-ranging primates are confronted with the challenge of maintaining an optimal range of body temperatures within a thermally dynamic environment that changes daily, seasonally, and annually. While many laboratory studies have been conducted on primate thermoregulation, we know comparatively little about the thermal pressures primates face in their natural, evolutionarily relevant environment. Such knowledge is critical to understanding the evolution of thermal adaptations in primates and for comparative evaluation of humans' unique thermal adaptations. We examined temperature and thermal environment in freeranging, mantled howling monkeys (Alouatta palliata) in a tropical dry forest in Guanacaste, Costa Rica. We recorded subcutaneous $\left(T_{\mathrm{sc}}\right)$ and near-animal ambient temperatures $\left(T_{\mathrm{a}}\right)$ from 11 animals over 1586.5 sample hours during wet and dry seasons. Howlers displayed considerable variation in $T_{\mathrm{sc}}$, which was largely attribut-
\end{abstract}

Temperature is a major factor affecting organisms because it directly impacts molecular, physiological, and behavioral processes (Pörtner et al., 2006). There is ample evidence that an animal's thermal environment and its ability to deal with temperature fluctuations have important short- and long-term consequences that are evolutionarily significant. Excess heat is known to disrupt reproductive processes and reduce cognitive ability (Dunbar, 1990; McMorris et al., 2006; Descamps et al., 2008; Megahed et al., 2008; Hansen, 2009). In free-ranging baboons, both cold and warm thermal stressors have been linked to increased interbirth interval, fewer menstrual cycles, lower conception and birth rates, higher infant and juvenile mortality, and reduced longevity (Ohsawa and Dunbar, 1984; Hill et al., 2000; Beehner et al., 2006). Thermal environment (including warm, cold, and mild habitats) has also been linked to a myriad of commonly measured behavioral variables such as rates of social contact, activity budgets, food consumption, and travel distances (Harrison, 1985; Agetsuma, 1995; Chiarello, 1995; Fernandez-Duque, 2003; Hanya, 2004; Hill, 2006; Baoping et al., 2009; Terrien et al., 2011; Nowack et al., 2013). Despite clear evidence linking temperature to behaviorally and evolutionarily important processes, we know relatively little about the able to circadian effects. Despite significant seasonal changes in the ambient thermal environment, howlers showed relatively little evidence for seasonal changes in $T_{\text {sc. }}$ Howlers experienced warm thermal conditions which led to body cooling relative to the environment, and plateaus in $T_{\mathrm{sc}}$ at increasingly warm $T_{\mathrm{a}}$. They also frequently faced cool thermal conditions $\left(T_{\mathrm{a}}<T_{\mathrm{sc}}\right)$ in which $T_{\mathrm{sc}}$ was markedly elevated compared with $T_{\mathrm{a}}$. These data add to a growing body of evidence that nonhuman primates have more labile body temperatures than humans. Our data additionally support a hypothesis that, despite inhabiting a dry tropical environment, howling monkeys experience both warm and cool thermal pressures. This suggests that thermal challenges may be more prevalent for primates than previously thought, even for species living in nonextreme thermal environments. Am J Phys Anthropol 000:000-000, 2014. () 2014 Wiley Periodicals, Inc.

thermoregulatory responses of wild primates to their natural environment.

Laboratory studies show that animals preferentially seek ambient temperatures that allow them to maintain optimal body temperature ranges without expending additional energy to cool or warm their body (Terrien et al., 2011). Animals often achieve this "thermoneutral zone" (TNZ) through a variety of behavioral mechanisms

Additional Supporting Information may be found in the online version of this article.

Grant sponsors: National Science Foundation; BCS-0720028 and BCS-070025; Ohio University Baker and Research Challenge Awards; Duke Arts and Sciences Council.

\footnotetext{
*Correspondence to: Cynthia L. Thompson, Department of Biomedical Sciences, Grand Valley State University, 231 Padnos Hall, Allendale, MI 49401, USA. E-mail: thompscy@gvsu.edu
}

Received 22 October 2013; accepted 23 February 2014

DOI: 10.1002/ajpa.22505

Published online 00 Month 2014 in Wiley Online Library

(wileyonlinelibrary.com). 
such as microhabitat selection, timing of activities, use of specific postures, huddling, or sunbathing (Terrien et al., 2011). If an animal falls outside of its TNZ, it is forced to expend more energy to maintain a given body temperature. For example, mammals will warm themselves by increasing thermogenesis through elevating thyroid hormones or shivering (Silva, 2003; Silvestri et al., 2005) while conversely using skin vasodilatation, increased blood flow to the limbs, sweating, or panting to help dissipate extreme heat (Elizondo, 1977; Terrien et al., 2011). Diurnal mammals also display a strong circadian rhythm in body temperature, with peaks during the day and low temperatures exhibited at night (with nocturnal animals exhibiting the reverse pattern; Refinetti, 2010). Non-human primates display considerable variation in both the daily and absolute range of body temperatures (Table 1). Although most of these thermoregulatory patterns have been examined experimentally under laboratory conditions, such studies fail to replicate the numerous factors that influence temperature regulation in the wild such as spatial and temporal variation in temperature; weather related variables including humidity, wind speed, and precipitation; food supply, quality, and distribution; predation; and social interactions. Additionally, many laboratory studies manipulate light cycles or temperature conditions in ways that may create artificial thermoregulatory patterns (Table 1). Given these challenges, thermoregulatory data from lab studies may not provide an ecologically, and therefore evolutionarily, relevant representation of how wild primates respond to thermal challenges throughout their environment (e.g., Geiser et al., 2007; Warnecke et al., 2007).

There have been few attempts to understand the thermoregulatory strategies employed by free-ranging primates in their natural environment. The only available body temperatures of wild primates have been measured on terrestrial hamadryas baboons living in an open and highly arid environment, nocturnal galagos, and fat-tailed dwarf and mouse lemurs which undergo torpor (although temperatures during nontorpor periods are also available) (Table 1). Hamadryas baboons living in their extreme environment offer only limited insight into generalized anthropoid thermoregulation as they likely possess their own derived heatstress adaptations. Nocturnal, small-bodied, and torpid strepsirrhines also offer little comparative insight into the essential thermal responses of most primate species to their environment.

Developing an understanding of the thermoregulatory patterns of more generalized anthropoids is critical for informing field primatological studies that examine variables impacted by thermoregulation, as well as providing baseline data for interpreting the evolution of human thermoregulation. Humans possess unmistakable adaptations to dissipate heat relative to non-human primates. In addition to lacking body fur, human skin has an increased concentration of eccrine sweat glands that can produce up to five times more sweat than chimpanzees and up to 100 times more than some mammals (Whitford, 1976; Zihlman and Cohn, 1988; Folk and Semken, 1991; Kenny and Journeay, 2010). This sweating greatly enhances evaporative cooling (Hanna and Brown, 1983; Folk and Semken, 1991; Jablonski, 2004; Kenny and Journeay, 2010) and can provide an additional avenue of heat loss during strenuous activities such as running (Carrier et al., 1984). Similarly, vasodilatation in humans enables heat loss by generating a 16-fold increase in blood flow to the skin, compared with only a three-fold increase in baboons (Wyss and Rowell, 1976; Kenny and Journeay, 2010). In comparison to the wide temperature variation seen in non-human primates, human core body temperatures vary only minimally for healthy individuals under a variety of thermal stressors (Table 1). While the unique thermoregulation of humans is well understood from a clinical perspective, we currently have little knowledge of the baseline anthropoid condition from which these adaptations evolved.

To characterize temperature and thermal environment of a generalized arboreal anthropoid, we monitored subcutaneous and near-animal ambient temperatures of free-ranging mantled howling monkeys (Alouatta palliata) living in a seasonally dry tropical forest at La Pacifica, Costa Rica. Using data from these animals, we will address five aims:

1. Assess the impact of sex and interindividual variation on body temperatures.

2. Document circadian variation in subcutaneous and ambient temperatures.

3. Evaluate seasonal temperature variation.

4. Analyze the temporal association between subcutaneous and ambient temperatures during circadian shifts.

5. Assess the response of subcutaneous temperature to the range of ambient environmental conditions experienced by howlers.

\section{METHODS Data collection}

We collected data on mantled howling monkeys at Hacienda La Pacifica, a private 1,980 hectare ranch located in the Province of Guanacaste, Costa Rica $\left(10^{\circ} 28^{\prime} \mathrm{N}, 85^{\circ} 07^{\prime} \mathrm{W}\right)$. La Pacifica is in the lowland tropical dry forest life zone and comprised of seasonally dry deciduous forest (Holdridge, 1967). During the dry season, daily temperature ranges from 22.5 to $34.1^{\circ} \mathrm{C}$ with a mean temperature of $28.1^{\circ} \mathrm{C}$ and $42 \%$ average relative humidity. Wet season temperatures range from 21.8 to $33.8^{\circ} \mathrm{C}\left(\bar{x}=26.1^{\circ} \mathrm{C}\right)$ with $94 \%$ average relative humidity. Mean annual precipitation is $1368 \mathrm{~mm}$ (range: 8312701 ), with heavy rains occurring during the wet season from May to October and relatively little precipitation during the dry season months of November-April (Daubenmire, 1972; Glander, unpublished data). Mantled howlers are mid-sized diurnal anthropoids (at La Pacifica, adult males: $\bar{x}=5.79 \mathrm{~kg}$; adult females: $\bar{x}=4.73 \mathrm{~kg}$; Glander, 2006) that feed primarily on fruit (12.5-49.9\% of diet) and leaves (48.2-69.3\%; Di Fiore et al., 2011). Despite living in large, mixed sex social groups (group size averages 10.2-21.8 individuals at various field sites in Guanacaste, Costa Rica; Di Fiore et al., 2011), rates of social interaction and physical contact (including huddling) are extremely low (Zucker and Clarke, 1998; Wang and Milton, 2003; Di Fiore et al., 2011). While howlers spend a relatively large amount of time resting (56.0-79.7\% of total activity budget: Di Fiore et al., 2011), their basal metabolism is comparable to other primates of similar body size (Milton et al., 1979; Ross, 1992). They also lack the digestive specializations of other folivorous primates (Milton, 1998) and have no known adaptive thermal specializations. Mantled 
TABLE 1. Absolute maximum and daily maximum body temperature ranges displayed by primates

\begin{tabular}{|c|c|c|c|c|c|}
\hline Species & Max range $\left({ }^{\circ} \mathrm{C}\right)$ & $\begin{array}{l}\text { Max daily } \\
\text { range }\left({ }^{\circ} \mathrm{C}\right)\end{array}$ & $\begin{array}{l}\text { Measurement } \\
\text { location }\end{array}$ & Environment & References \\
\hline Cheirogaleus crossleyi & $(25.0)$ & $(25.0)$ & $\mathrm{S}$ & Wild & Blanco and Rahalinarivo, 2010 \\
\hline Cheirogaleus medius & $>10.0(24.9)$ & $(24.9)$ & IP, $\mathrm{S}$ & Wild & Dausmann et al., 2004, 2005 \\
\hline Eulemur fulvus & 1.0 & & IP & Captive & Erkert and Cramer, $2006^{\mathrm{a}, \mathrm{b}}$ \\
\hline Galago moholi & $6.6(>10.0)$ & $5.3(>10.0)$ & IP & Wild & $\begin{array}{l}\text { Mzilikazi et al., 2006; Nowack } \\
\text { et al., 2010 }\end{array}$ \\
\hline Microcebus berthae ${ }^{\mathrm{d}}$ & $6.7(>30.0)$ & $2.7(>30.0)$ & IP & Wild & $\begin{array}{l}\text { Schmid et al., } 2000^{\text {c }} \text {; Ortmann } \\
\quad \text { et al., } 1997^{\mathrm{c}}\end{array}$ \\
\hline Microcebus griseorufus & $(27.0)$ & (23) & $\mathrm{S}$ & Wild & $\begin{array}{l}\text { Kobbe and Dausmann, } 2009 \\
\text { Kobbe et al., } 2011\end{array}$ \\
\hline Microcebus murinus & $<4.0(>25.0)$ & $<4.0$ & $\mathrm{~S}$ & Wild & $\begin{array}{l}\text { Schmid and Speakman, 2000, } \\
\text { 2009; Schmid, 2001; Vuarin } \\
\text { et al., 2013; Ortmann et al., } \\
1997^{\mathrm{c}}\end{array}$ \\
\hline Microcebus murinus & $2.2(>20.0)$ & $2.2(>20.0)$ & IP & Captive & $\begin{array}{l}\text { Aujard and Vasseur, 2001; Per- } \\
\text { ret and Aujard, } 2001^{\text {b }} \text {; Genin } \\
\text { and Perret, } 2003^{\text {bee }} \text {; Séguy } \\
\text { and Perret, } 2005\end{array}$ \\
\hline Microcebus ravelobensis & $>2.1(>10.0)$ & $>2.1(>10.0)$ & IP & Wild & Lovegrove et al., in press \\
\hline Nycticebus coucang & 5.6 & 4 & $\mathrm{R}$ & Captive & Müller, 1979ª \\
\hline Otolemur crassicaudatus & 0.6 & & $\mathrm{R}$ & Captive & Hiley, $1976^{\mathrm{a}}$ \\
\hline Tarsius syrichta & $>4.0$ & $>2.0$ & $\mathrm{~S}$ & Wild & Lovegrove et al., in press \\
\hline Tarsius syrichta & 2.0 & & $\mathrm{R}$ & Captive & McNab and Wright, $1987^{\mathrm{a}}$ \\
\hline Aotus trivirgatus & 3.8 & $1.3-2.1$ & $\mathrm{R}$ & Captive & $\begin{array}{l}\text { Le Maho et al., } 1981^{\mathrm{a}} \text {; Hoban } \\
\text { et al., } 1985^{\mathrm{b}}\end{array}$ \\
\hline Aotus lemurinus & 2.0 & 1.5 & IP & Captive & Erkert and Gröber, $1986^{\mathrm{b}}$ \\
\hline Cebus albifrons & 3.0 & 3.0 & IP & Captive & Winget et al., 1968 \\
\hline Saimiri sciureus & $2.5-2.7$ & $2.0-2.7$ & $\mathrm{H}, \mathrm{IP}, \mathrm{R}$ & Captive & 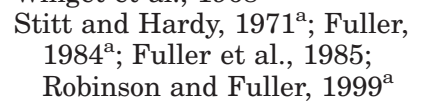 \\
\hline Erythrocebus patas & 2.1 & 2.0 & $\mathrm{~A}$ & Captive & Simpson and Galbraith, 1906 \\
\hline Macaca fuscata & 3.4 & 3.4 & IP, $\mathrm{R}$ & Captive & $\begin{array}{l}\text { Nakayama et al., } 1971^{\mathrm{a}} \text {; Takasu } \\
\quad \text { et al., } 2002^{\mathrm{b}}\end{array}$ \\
\hline Macaca mulatta & $1.6-2.6$ & $1.0-1.6$ & $\mathrm{~A}, \mathrm{IP}, \mathrm{R}, \mathrm{RP}$ & Captive & $\begin{array}{l}\text { Simpson and Galbraith, 1906; } \\
\text { Johnson and Elizondo, 1979; } \\
\text { Tapp and Natelson, 1989; } \\
\text { Honnebiere et al., } 1992\end{array}$ \\
\hline Macaca fascicularis & 3.5 & & A & Captive & Simpson and Galbraith, 1906 \\
\hline Papio cynocephalus & 1.8 & & $\mathrm{R}$ & Captive & Hiley, $1976^{\mathrm{a}}$ \\
\hline Papio hamadryas & 2.5 & 2.5 & $\mathrm{~A}$ & Captive & Simpson and Galbraith, 1906 \\
\hline P. hamadryas ursinus & $>3.0$ & 1.7 & IP & Captive & $\begin{array}{l}\text { Mitchell et al., } 2009^{\mathrm{a}, \mathrm{f}} ; \text { Nyaku- } \\
\text { dya et al., } 2012\end{array}$ \\
\hline P. hamadryas ursinus & 5.3 & 5.3 & IP & Wild & Brain and Mitchell, 1999 \\
\hline Pan troglodytes & 4.0 & & $\mathrm{R}$ & Captive & Hiley, $1976^{\mathrm{a}}$ \\
\hline Homo sapiens & $0.5-1.6$ & 1.6 & $\mathrm{AC}, \mathrm{E}, \mathrm{O}, \mathrm{R}$ & See citations & $\begin{array}{l}\text { Mackowiak et al., 1992; Refi- } \\
\text { netti and Menaker, 1992 } \\
\text { Webb, } 1992^{\mathrm{a}} \text {; Refinetti, } 2010^{\mathrm{g}}\end{array}$ \\
\hline
\end{tabular}

Temperatures in parentheses denote torpid/hibernating animals.

Measurement location: A: axillary; AC: auditory canal; E: esophageal; H: hypothalamic; IP: intraperitoneal; O: oral; R: rectal; RP: retroperitoneal; S: skin (for small mammals, skin temperature approximates core body temperature: Dausmann, 2005).

${ }^{a}$ Study manipulated ambient temperature.

${ }^{\mathrm{b}}$ Manipulated light cycle.

${ }^{\mathrm{c}}$ Animals were wild caught and housed in outdoor cages.

d Published as M. myoxinus: Rasoloarison et al., 2000.

${ }^{\mathrm{e}}$ Manipulated access to food.

${ }^{\mathrm{f}}$ Manipulated access to water.

${ }^{\mathrm{g}}$ Review article with varying methods.

howlers at La Pacifica inhabit both riparian forests and more seasonal dry, nonriver forest patches (Glander, 1975; Glander and Nisbett, 1996).

We recorded subcutaneous $\left(T_{\mathrm{sc}}\right)$ and near-animal ambient temperature $\left(T_{\mathrm{a}}\right)$ from 11 animals from two groups during intermittent field seasons from March 2010 to August 2012, yielding a total of 1586.5 sample hours $(N=9519$ temperature sample points; Table 2). Sampling was conducted during both wet $(1396.0 \mathrm{hr}$; $N=8376)$ and dry (190.5 hr; $N=1143)$ seasons and var- ied in length for subjects (Table 2). Animals were darted following Glander et al. (1991). We recorded $T_{\mathrm{sc}}$ by implanting a small $(17 \times 6 \times 6 \mathrm{~mm} 3.3 \mathrm{~g})$ sterile and intact temperature data logger (iButton DS1922T: Maxim Integrated Products) directly under the skin between the shoulder blades under general anesthesia (Lovegrove, 2009). Temperature loggers were accurate to $\pm 0.06^{\circ} \mathrm{C}$. A second iButton temperature logger was loosely attached (i.e., not touching the skin) to an anklet or neck collar to record $T_{\mathrm{a}}$. This placement has the 
TABLE 2. Mantled howler subjects and data collection conditions

\begin{tabular}{|c|c|c|c|c|c|c|c|}
\hline Group & Subject & Weight $(\mathrm{kg})^{\mathrm{a}}$ & Sex & Recording Date & Jacket & Season & Sample (h) \\
\hline \multirow[t]{12}{*}{1} & \multirow[t]{3}{*}{ Abita } & \multirow[t]{2}{*}{5.20} & \multirow[t]{3}{*}{$\mathrm{F}$} & July 2010 & $\mathrm{Y}^{\mathrm{b}}$ & Wet & 24.5 \\
\hline & & & & July 2010 & $\mathrm{~N}$ & Wet & 252.3 \\
\hline & & 5.20 & & March 2010 & $\mathrm{Y}$ & Dry & 46.8 \\
\hline & \multirow[t]{2}{*}{ Alana } & 4.25 & \multirow[t]{2}{*}{$\mathrm{F}$} & March 2010 & $\mathrm{Y}$ & Dry & 47.5 \\
\hline & & 4.40 & & July 2010 & $\mathrm{Y}$ & Wet & 24.0 \\
\hline & Calliope & 4.40 & $\mathrm{~F}$ & July 2010 & $\mathrm{Y}$ & Wet & 48.7 \\
\hline & \multirow[t]{3}{*}{ Dyani } & 6.40 & \multirow[t]{3}{*}{ M } & March 2010 & $\mathrm{Y}$ & Dry & 47.7 \\
\hline & & 6.00 & & July 2010 & $\mathrm{Y}$ & Wet & 47.7 \\
\hline & & 6.35 & & July 2011 & $\mathrm{Y}$ & Wet & 63.3 \\
\hline & \multirow[t]{3}{*}{ St Patrick } & 6.00 & \multirow[t]{3}{*}{ M } & March 2010 & $\mathrm{Y}$ & Dry & 48.5 \\
\hline & & 6.30 & & July 2010 & $\mathrm{Y}^{\mathrm{b}}$ & Wet & 47.8 \\
\hline & & & & July 2010 & $\mathrm{~N}$ & Wet & 306.7 \\
\hline \multirow[t]{6}{*}{2} & Agate & 4.75 & $\mathrm{~F}$ & August 2012 & $\mathrm{Y}$ & Wet & 34.0 \\
\hline & Audio Monkey & 4.25 & $\mathrm{~F}$ & August 2012 & $\mathrm{Y}$ & Wet & 35.3 \\
\hline & Audrey & 3.80 & $\mathrm{~F}$ & August 2012 & $\mathrm{~N}$ & Wet & 83.0 \\
\hline & Wingette & 3.75 & $\mathrm{~F}$ & August 2012 & $\mathrm{Y}$ & Wet & 32.8 \\
\hline & Orf & 6.50 & $\mathrm{M}$ & July 2011 & $\mathrm{~N}$ & Wet & 194.0 \\
\hline & Wings & 6.00 & $\mathrm{M}$ & July 2011 & $\mathrm{~N}$ & Wet & 204.8 \\
\hline
\end{tabular}

a Taken after capture.

${ }^{\mathrm{b}}$ Individual initially wore jacket for 1-2 days and then was re-captured, jacket removed and re-released with only temperature recording devices.

advantage of recording ambient temperatures at the animal's location, rather than at a remote weather station, providing more accurate measurement of the animal's actual thermal environment (Hetem et al., 2007). We synchronized loggers to record temperatures at $10 \mathrm{~min}$ intervals. At the end of sampling periods, animals were recaptured to explant temperature sensors using the same procedures involved in capture and implant. The minimum time between subsequent captures was $46 \mathrm{hr}$; recaptures were needed to remove extra devices carried by animals for a concurrent project (below). In all cases, we waited $>14 \mathrm{hr}$ postcapture to collect temperature data to avoid thermal effects of tiletamine-based anesthesia on primates (Lopez et al., 2002). During some sampling periods $(500.1 \mathrm{hr} ; 31.5 \%$ of total sampling time; Table 2), animals were fitted with a jacket designed for primates (Lomir Biomedical) to carry devices for a concurrent project (Williams et al., 2008; Vinyard et al., 2012). The total weight carried by jacketed subjects was $\sim 300 \mathrm{~g}$, which is less than the weight of infants carried by females. Jackets did not hinder movement. The jacket did not have a significant impact on daily $T_{\mathrm{sc}}$ minimum (ANCOVA: $F=0.44, P=0.513$ ), maximum $(F=0.58, P=0.463)$, or mean $(F=0.01, P=0.933)$ when controlling for $T_{\mathrm{a}}$, season, and individual. For the two individuals with jacketed and nonjacketed sample periods, both showed significant, but minimal effects of the jacket on $T_{\mathrm{sc}}$ (two sample $t$-test: Abita: $t=2.72$, $P=0.007$, mean difference $=0.24^{\circ} \mathrm{C}$; St. Patrick: $t=-7.15, P<0.001$, mean difference: $\left.-0.53^{\circ} \mathrm{C}\right)$, with the presence or absence of the jacket explaining $0.5 \%$ of variation in $T_{\mathrm{sc}}$ for Abita and $2.4 \%$ for St. Patrick during the same season. The jacket did not have a significant effect on daily $T_{\mathrm{sc}}$ and $T_{\mathrm{a}}$ cross-correlation coefficients (CCF; two sample $t$-test; $t=-1.01, P=0.318$ ) nor on $\mathrm{CCF}$ lag time (two sample $t$-test; $t=-0.52, P=0.602$ ), indicating the jacket did not change the nature of the $T_{\mathrm{a}} / T_{\mathrm{sc}}$ relationship. Given these results, we have taken a conservative approach and opted to control for the relatively small effect of jackets in appropriate statistical analyses. All procedures were approved by the NEOMED, Duke University, and Ohio University IACUCs.

\section{Data analysis}

Data were analyzed in two formats: (1) the data set containing all samples taken at $10 \mathrm{~min}$ intervals $(N=9519)$, and (2) a data set summarizing temperature variables by day (e.g., daily mean temperature, daily minimum, daily maximum), for days with $>14$ sampling hr $(N=67)$. To test the effects of sex and season on $T_{\mathrm{sc}}$, we conducted ANCOVAs on the impact of sex, jacket, season, and $T_{\mathrm{a}}$ (covariate) on daily mean, minimum, and maximum $T_{\mathrm{sc}}$ (Aims 1, 3). For a more general assessment of the variables impacting $T_{\mathrm{sc}}$, we conducted ANCOVAs for mean, minimum, and maximum daily $T_{\mathrm{sc}}$, testing the effect of the interindividual differences, jacket, and season while controlling for $T_{\mathrm{a}}$ as a covariate (Aims 1, 3). [Sex and interindividual differences could not be combined in a single ANCOVA due to multicollinearity.] For both tests, the $T_{\text {a }}$ covariate selected was analogous to the $T_{\mathrm{sc}}$ variable analyzed (e.g., minimum $T_{\mathrm{a}}$ was used as covariate for the ANCOVA on minimum $T_{\mathrm{sc}}$ ). Interindividual differences were a significant variable in the ANCOVA, so we conducted an ANOVA comparing all animals via a Tukey HSD post hoc test to better quantify pairwise individual differences in $T_{\mathrm{sc}}$ (Aim 1).

To assess circadian variation, ranges and $\mathrm{CVs}$ were calculated for daily $T_{\mathrm{sc}}$ and $T_{\mathrm{a}}$ values (Aim 2). To further assess seasonal effects, we compared daily mean, minimum, and maximum $T_{\mathrm{sc}}$ of individuals that were sampled in both seasons via a permutation test for matched pairs conducted with 1000 random permutations created from the original data set (Aim 3). Although the original (nonpermuted) sample size was very low (4 individuals: Abita, Alana, St. Patrick, and Dyani), this test does provide an additional means of assessing seasonal effects (compared with the ANCOVA) on individuals. To assess whether animals experience seasonal shifts in their thermal environment, we compared daily mean, maximum, and minimum $T_{\text {a }}$ between wet and dry seasons via two sample $t$-tests (Aim 3). A nested ANOVA (no covariates) was also performed on $T_{\mathrm{sc}}$ to directly compare the variation attributable to circadian vs. seasonal effects (Aims 2, 3). 
TABLE 3. Daily and absolute minimum, maximum, and mean subcutaneous and near-animal ambient temperatures by season and sex

\begin{tabular}{|c|c|c|c|c|c|c|c|c|c|c|c|c|}
\hline \multirow[b]{3}{*}{ Season } & \multirow[b]{3}{*}{ Sex } & \multicolumn{5}{|c|}{$T_{\mathrm{sc}}\left({ }^{\circ} \mathrm{C}\right)$} & \multicolumn{5}{|c|}{$T_{\mathrm{a}}\left({ }^{\circ} \mathrm{C}\right)$} & \multirow{3}{*}{$\begin{array}{c}\text { Sample } \\
\text { Hours }\end{array}$} \\
\hline & & \multicolumn{2}{|c|}{ Absolute } & \multicolumn{3}{|c|}{$\bar{x}$ Daily } & \multicolumn{2}{|c|}{ Absolute } & \multicolumn{3}{|c|}{$\bar{x}$ Daily } & \\
\hline & & Min & Max & Min & Max & $\bar{x}$ & Min & Max & Min & Max & $\bar{x}$ & \\
\hline \multirow[t]{2}{*}{ Dry } & Male & 35.23 & 40.87 & 35.95 & 40.07 & 37.52 & 25.29 & 44.89 & 21.29 & 39.47 & 32.62 & 96.2 \\
\hline & Female & 35.29 & 39.70 & 35.93 & 39.54 & 37.36 & 26.50 & 41.01 & 29.21 & 37.35 & 32.38 & 94.3 \\
\hline \multirow[t]{2}{*}{ Wet } & Male & 30.97 & 42.34 & 35.44 & 40.18 & 37.57 & 22.59 & 42.58 & 25.06 & 36.30 & 29.83 & 863.2 \\
\hline & Female & 32.42 & 42.64 & 34.60 & 39.70 & 36.78 & 22.34 & 40.25 & 24.30 & 36.46 & 29.15 & 532.8 \\
\hline
\end{tabular}

TABLE 4. ANCOVA for the effect of season, individual, and ambient temperature on daily maximum, minimum, and mean subcutaneous temperatures

\begin{tabular}{|c|c|c|c|c|c|c|c|c|c|}
\hline \multirow[b]{2}{*}{ Variable } & \multicolumn{3}{|c|}{$T_{\mathrm{sc}}$ Maximum } & \multicolumn{3}{|c|}{$T_{\mathrm{sc}}$ Minimum } & \multicolumn{3}{|c|}{$T_{\mathrm{sc}}$ Mean } \\
\hline & $F$ & $P$ & Partial $\eta^{2}$ & $F$ & $P$ & Partial $\eta^{2}$ & $F$ & $P$ & Partial $\eta^{2}$ \\
\hline Season & 0.46 & 0.502 & 0.09 & 3.72 & 0.059 & 0.07 & 1.32 & 0.256 & 0.02 \\
\hline$T_{\mathrm{a}}$ & 12.06 & 0.001 & 0.19 & 10.25 & 0.002 & 0.16 & $\mathbf{1 1 . 5 7}$ & 0.001 & 0.18 \\
\hline Individual & 2.33 & 0.023 & 0.31 & 3.70 & $<0.001$ & 0.43 & 5.74 & $<0.001$ & 0.52 \\
\hline
\end{tabular}

Significant values $(P<0.05)$ in bold.

We conducted cross-correlations between $T_{\mathrm{a}}$ and $T_{\mathrm{sc}}$ on a per day interval for days with $>14 \mathrm{hr}$ of data (Aim 4). CCFs were evaluated at lags up to $\pm 2.3 \mathrm{hr}$ (preliminary tests with greater lags did not yield higher CCF values). To determine whether the relationship between $T_{\mathrm{a}}$ and $T_{\text {sc }}$ varied with specific thermal conditions, we conducted a regression for maximum daily CCF values including daily means, maximums, and minimums for $T_{\mathrm{a}}$ and $T_{\mathrm{sc}}$ and CCF lag times (Aim 4). The Bayesian Information Criterion (BIC) was used to determine the best model. Regression residuals from reported models displayed normality (Kolmogrov-Smirnov test: $K-S=0.10$, $P=0.20$ ), indicating the test passed parametric criteria. We also calculated maximum $\mathrm{CCF}$ and lag values separately for daylight $(6: 30-18: 30)$ and nighttime (all other hours) samples. We compared the respective daily daytime and nighttime maximum CCFs via paired $t$-tests (Aim 4).

To determine the range of $T_{\mathrm{sc}}$ displayed at various $T_{\mathrm{a}}$ (Aim 5), we calculated the mean and coefficients of variation (CV) for observed $T_{\mathrm{sc}}$ over $0.5^{\circ} \mathrm{C}$ increments of $T_{\mathrm{a}}$. Mean and CV $T_{\mathrm{sc}}$ values were correlated with the lower limit of the ambient interval range via Pearson's product-moment (Aim 5). Large variation in $T_{\mathrm{sc}}$ within $T_{\mathrm{a}}$ intervals suggests animals are within their TNZ, as body temperatures can vary in this range without energetic expense and active thermoregulation (Romanovsky et al., 2002). Low variation suggests animals are actively controlling body temperature. All tests were evaluated at a two-tailed $\alpha=0.05$ except where noted above.

\section{RESULTS}

\section{Sex and interindividual effects}

Absolute and daily values for $T_{\mathrm{a}}$ and $T_{\mathrm{sc}}$ varied with sex and season (Table 3 ). There was a significant impact of sex (when controlling for $T_{\mathrm{a}}$, jacket, and season) on daily mean (ANCOVA: sex: $F=7.37, P=0.009$ ) and maximum $T_{\text {sc }}$ values (ANCOVA: $F=4.38, P=0.041$ ) with males displaying warmer temperatures than females (Table 3). There was not a significant sex effect on mini- mum $T_{\mathrm{sc}}$ (ANCOVA: $\left.F=2.08, P=0.154\right)$. There were significant interindividual differences in $T_{\mathrm{sc}}$ (Table 4 ) and post hoc tests (with no covariates) revealed that $72.7 \%$ $(N=40)$ of all possible pairwise interindividual comparisons showed significant differences. For individual animals over the entire study period, $T_{\mathrm{sc}}$ varied from $3.8-11.4^{\circ} \mathrm{C}$ with a mean range of $7.5 \pm 2.2^{\circ} \mathrm{C}$.

\section{Circadian and seasonal effects}

Individual $T_{\mathrm{sc}}$ varied up to $11.4^{\circ} \mathrm{C}$ within a day (minimum daily range $=2.1^{\circ} \mathrm{C}$ ), with a mean daily range of $4.7 \pm 1.9^{\circ} \mathrm{C}$ (Fig. 1; Supporting Information). Within-day $T_{\text {sc }}$ CVs ranged from $1.3-6.7 \%$ with a mean $\mathrm{CV}$ of $3.1 \pm 1.3 \%$. For comparison, the total range of all observed $T_{\mathrm{sc}}$ was $11.7^{\circ} \mathrm{C}$ with a $\mathrm{CV}$ of $4.0 \%$. $T_{\mathrm{a}}$ was more variable than $T_{\mathrm{sc}}$, with maximum daily ranges up to $18.7^{\circ} \mathrm{C}$ (minimum: $5.9^{\circ} \mathrm{C}$ ) and a mean daily range of $11.4 \pm 2.5^{\circ} \mathrm{C}$. Within-day $T_{\mathrm{a}} \mathrm{CVs}$ ranged from $3.1-16.1 \%$ with a mean CV of $9.9 \pm 3.1 \%$; total variation for all recorded $T_{\mathrm{a}}$ was $12.7 \%$. During the nighttime, $T_{\mathrm{a}}$ ranged from $22.3-36.9^{\circ} \mathrm{C}\left(\bar{x}=28.1 \pm 3.2^{\circ} \mathrm{C}\right)$ compared with daytime temperatures between $22.4-44.9^{\circ} \mathrm{C} \quad(\bar{x}=31.8 \pm$ $\left.3.5^{\circ} \mathrm{C}\right) . T_{\mathrm{sc}}$ varied from 31.9 to $39.7^{\circ} \mathrm{C}\left(\bar{x}=36.5 \pm 1.3^{\circ} \mathrm{C}\right)$ at night and $31.0-42.6^{\circ} \mathrm{C}\left(\bar{x}=38.1 \pm 1.2^{\circ} \mathrm{C}\right)$ during the day. A nested ANOVA found that circadian effects explained $33.7 \%$ of variation in $T_{\mathrm{sc}}$, compared with only $0.2 \%$ explained by seasonal effects.

$T_{\text {a }}$ measures showed that howlers experience seasonal changes in their thermal environment (Table 3). Daily $T_{\mathrm{a}}$ means and minimums were significantly cooler in the wet season (means: mean difference $=3.53^{\circ} \mathrm{C}$, two sample $t$-test: $t=4.49, P<0.001$; minimums: mean difference $=4.08^{\circ} \mathrm{C}$, two sample $t$-test: $\left.t=6.53, P<0.001\right)$, while maximums did not significantly differ (mean difference $=2.05^{\circ} \mathrm{C}$, two sample $t$-test: $t=1.52, P=0.171$ ) Despite these changes in thermal environment, season did not affect daily $T_{\mathrm{sc}}$ measures when controlling for jacket, sex, and $T_{\mathrm{a}}$ (Table 4 ). Removing $T_{\mathrm{a}}$ as a covariate did not change these relationships. For the four individuals sampled in both seasons, animals had lower, but non-significant, absolute minimum $T_{\mathrm{sc}}$ during the wet 


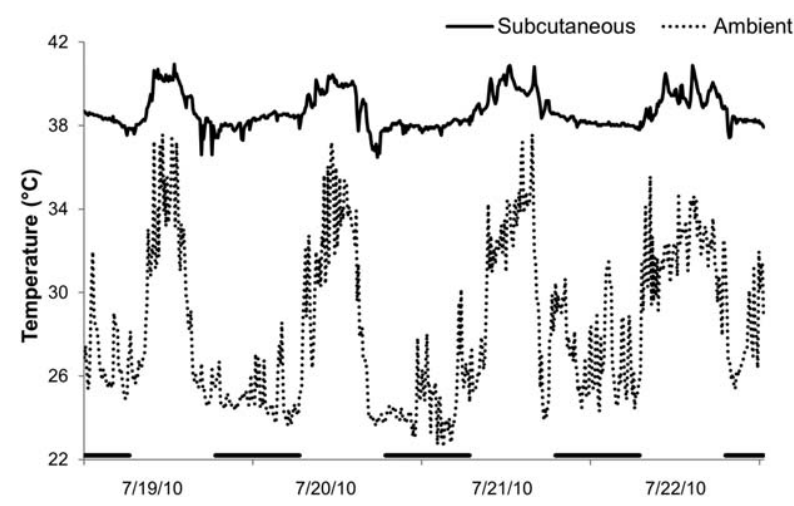

Fig. 1. Representative temperature sequence from a male howler (Wings) during the wet season, showing circadian variation in $T_{\mathrm{a}}$ and $T_{\mathrm{sc}}$. Horizontal bars indicate nighttime hours (06:30-18:30).

season (mean difference: $1.66^{\circ} \mathrm{C}$, permutation test: $P=0.058$ ), while maximums and means did not appreciably differ between seasons (maximums: mean difference $=-0.48^{\circ} \mathrm{C}$, permutation test: $P=0.349$; means: mean difference $=0.18^{\circ} \mathrm{C}$, permutation test: $P=0.483$ ).

\section{The relationship between $T_{s c}$ and $T_{a}$}

Daily maximum CCFs between $T_{\mathrm{sc}}$ and $T_{\mathrm{a}}$ were positive for 66 out of 67 days $(\bar{x}=0.70 \pm 0.18)$ and all but one day yielded significant values. However, the maximum CCFs spanned a wide range of lag times. The modal lag time (in 10 min increments) was 0 , which represented $43.3 \%(N=29)$ of days. Positive lag times, in which $T_{\mathrm{a}}$ led changes in $T_{\mathrm{sc}}$ characterized $32.8 \%(N=22)$ of days, while $23.9 \%(N=16)$ of days displayed negative lag times, in which $T_{\mathrm{sc}}$ led changes in $T_{\mathrm{a}}$. The model best predicting daily CCF values (using BIC) included the variables daily mean $T_{\mathrm{a}}$ (standardized $\beta=-0.48$, $P<0.001$ ) and daily maximum $T_{\mathrm{a}}$ (standardized $\beta=0.54$, $P<0.001)$. The second best model included these variables in addition to maximum $T_{\mathrm{sc}}$, but this variable was not significant (standardized $\beta=0.13, P=0.380$ ). For temperature samples over all sample days, CCFs between $T_{\mathrm{sc}}$ and $T_{\mathrm{a}}$ were much stronger during daytime hours $(\bar{x} \quad \mathrm{CCF}=0.524)$ than nighttime hours $(\bar{x}$ $\mathrm{CCF}=0.184$; paired $t$-test: $t=-4.81, P<0.001)$, reflecting that $T_{\mathrm{sc}}$ rises and falls concurrently with daytime $T_{\mathrm{a}}$ shifts (Fig. 1), but $T_{\mathrm{sc}}$ remains level as $T_{\mathrm{a}}$ declines to cooler nighttime lows. These differences also indicate that $T_{\text {a }}$ measurements were not being impacted by residual body heat from the animal.

Overall, the average $T_{\mathrm{sc}}$ displayed was strongly correlated with observed $T_{\mathrm{a}}$ (Pearson's: $r=0.96, P<0.001$; Fig. 2). However, $T_{\mathrm{sc}}$ values plateaued at $T_{\mathrm{a}}>41^{\circ} \mathrm{C}$ (Fig. 2, box). Likewise, $95 \%$ of dry season samples with $T_{\mathrm{sc}}<T_{\mathrm{a}}$ occurred at $T_{\mathrm{a}}>38.1^{\circ} \mathrm{C}$. The CVs for $T_{\mathrm{sc}}$ at observed $T_{\mathrm{a}}$ were relatively constant at lower $T_{\mathrm{a}}$, but decreased at warmer $T_{\mathrm{a}}$ (Pearson's: $r=-0.48, P=0.001$; Fig. 2), suggesting that $T_{\mathrm{sc}}$ is being actively controlled at these warm $T_{\mathrm{a}}$.

Warm thermal conditions $\left(T_{\mathrm{a}}>T_{\mathrm{sc}}\right)$ occurred less frequently than cool conditions $\left(T_{\mathrm{a}}<T_{\mathrm{sc}}\right)$, with only $10.4 \%$ of dry seasons samples and $0.06 \%$ of wet season samples displaying $T_{\mathrm{a}}>T_{\mathrm{sc}}$ (Fig. 3). Additionally, under cool thermal conditions animals displayed a greater magnitude of difference between $T_{\mathrm{a}}$ and $T_{\mathrm{sc}}$ than under warm condi-

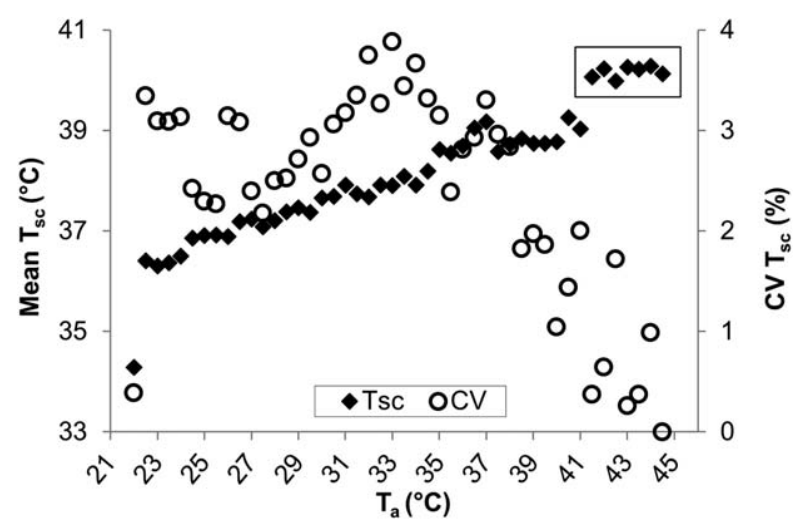

Fig. 2. Observed mean subcutaneous temperatures $\left(T_{\mathrm{sc}}\right)$ and their coefficients of variation (CV) at near-animal ambient temperatures $\left(T_{\mathrm{a}}\right)$. Box $=$ plateau in $T_{\mathrm{sc}}\left(\bar{x}=40.2^{\circ} \mathrm{C}\right)$ at warm $T_{\mathrm{a}}$. Increased $\mathrm{CV}$ values indicate more variable heat loss from the skin at energetically neutral $T_{\mathrm{a}}$ values.

tions, with a maximum difference of $15.4^{\circ} \mathrm{C}$ in cool conditions vs. $4.8^{\circ} \mathrm{C}$ in warm conditions (Fig. 3).

\section{DISCUSSION}

We have provided the first characterization of temperatures and thermal environment in a free-ranging, thermally generalized arboreal anthropoid. Howling monkeys experience a dynamic thermal environment and appear to have flexible body temperatures that respond to ambient conditions. Despite living in a dry tropical forest, howlers at La Pacifica also appear to be influenced by both warm and cool thermal pressures. While many primate studies invoke thermoregulatory explanations, we rarely have measures of body temperatures or even a basic understanding of the species' thermoregulatory patterns to support these hypothesized relationships. Our data show that thermal pressures (both cool and warm) may be more widespread in primates than previously thought, including species living in thermal environments traditionally viewed as "mild." Understanding the biology behind how free-ranging primates mediate ambient thermal conditions and body temperature will allow us to more accurately model how behavioral and physiological variables are impacted by thermoregulatory processes. This is critical for primatological studies that measure variables heavily influenced by thermoregulation such as ranging behavior, dietary preferences, or food consumption.

Howlers displayed an impressive amount of total, daily, and within-individual variability in $T_{\mathrm{sc}}$, as well as significant variation between individuals and the sexes (Tables 3 and 4). The sex differences in body temperatures found here are common for many mammals (e.g., Gordon, 1990; Cryan and Wolf, 2003; Lu and Dai, 2009). Despite the limited data available on wild primates (Table 1), this adds to growing evidence that body temperatures are more labile in non-human primates than in humans. In addition to the minimal overall deviation in human core body temperature (Table 1), the average difference in core temperature between the onset of shivering and sweating ranges only $0.1-0.2^{\circ} \mathrm{C}$ in humans, with mean $T_{\mathrm{sc}}$ varying only $5.2^{\circ} \mathrm{C}$ between these behaviors (Webb, 1992). As an illustrative comparison, howler $T_{\text {sc }}$ in this study varied over twice this range $\left(11.7^{\circ} \mathrm{C}\right.$ : Table 3) with no observed sweating or shivering 


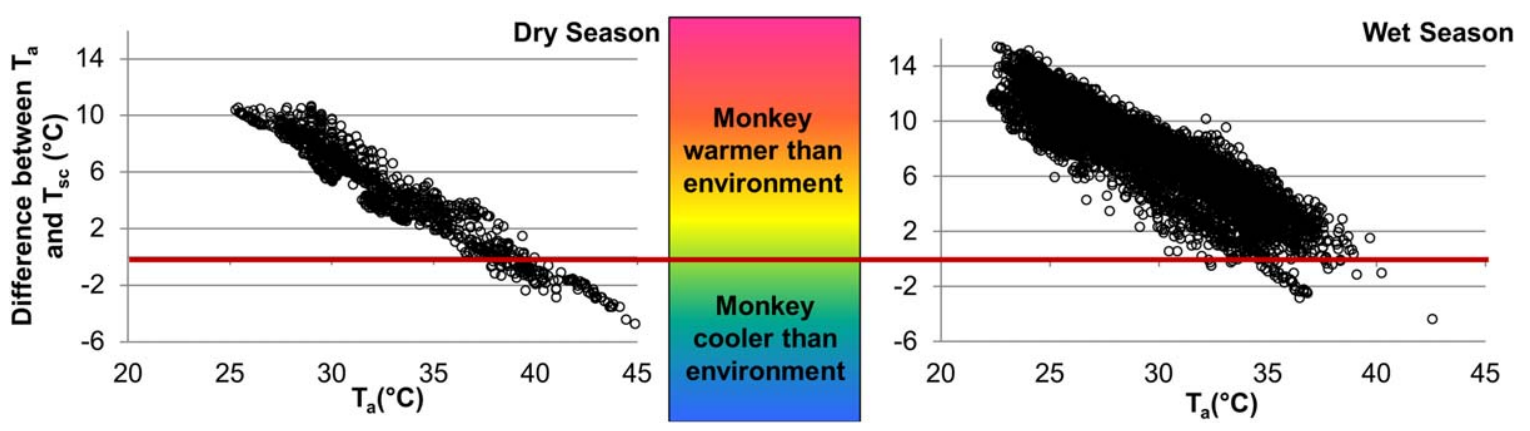

Fig. 3. Magnitude of differences between subcutaneous $\left(T_{\mathrm{sc}}\right)$ and near-animal ambient temperatures $\left(T_{\mathrm{a}}\right)$, by season. Temperatures above red line indicate $T_{\mathrm{sc}}>T_{\mathrm{a}}$, temperatures below, $T_{\mathrm{sc}}<T_{\mathrm{a}}$. [Color figure can be viewed in the online issue, which is available at wileyonlinelibrary.com.]

(although animals were only visually observed during the day). Likewise, human TNZ estimates have a range of $\sim 2{ }^{\circ} \mathrm{C}$ (Erikson et al., 1956; Andersen and Hellström, 1960; Brengelmann and Savage, 1997) while the estimated TNZs for captive primates are much broader: $5.9^{\circ} \mathrm{C} \quad\left(24.7-30.6^{\circ} \mathrm{C}\right)$ for rhesus macaques (Macaca mulatta; Johnson and Elizondo, 1979), $10.0^{\circ} \mathrm{C}$ (25.0$35.0^{\circ} \mathrm{C}$ ) for squirrel monkeys (Saimiri sciureus; Stitt and Hardy, 1971), and $8.0^{\circ} \mathrm{C}\left(25.0-33.0^{\circ} \mathrm{C}\right)$ for slow lorises (Nycticebus coucang; Müller, 1979). Wild fat-tailed dwarf lemurs (Cheirogaleus medius) have a $\sim 3^{\circ} \mathrm{C}\left(25.0-28.0^{\circ} \mathrm{C}\right)$ estimated TNZ during nontorpid periods (Dausmann et al., 2009). While captivity may not provide the most ecologically relevant measure of TNZ, the consistent difference in temperature variability seen between humans and non-human primates supports the notion that nonhuman primates have more labile body temperatures.

In this study, daily $T_{\mathrm{sc}}$ variation within individuals was nearly as high as the variation in the total data set, suggesting that the thermal factors most frequently impacting howlers are short-term, circadian variations, rather than longer-term seasonal changes or multiday weather patterns (e.g., storms, hot spells, etc.). The prevalence of howlers experiencing cool conditions $\left(T_{\mathrm{a}}<T_{\mathrm{sc}}\right)$ and the reduced nighttime correlation between $T_{\text {sc }}$ and $T_{\mathrm{a}}$ in this study also support the idea that daily variation, particularly cooler nighttime temperatures, may be the most frequent thermal pressure for howlers. This observation has far reaching implications for the study of primate nocturnal activity, including night ranging and sleeping site selection. It also means that the period of the coolest thermal stress is often not being monitored by observers. Precipitation may also be a significant contributing factor in short-term thermal pressures, since the evaporation of water from animals will produce a cooling effect. Yet, it should be noted that the relative constancy of $T_{\mathrm{sc}}$ over seasons, despite experiencing significantly cooler temperatures in the wet season, does imply that animals are using either behavioral or physiological mechanisms to maintain stable body temperatures in the face of a changing thermal environment. This varying thermoregulatory load could help explain various seasonal changes observed in primates including shifts in feeding and ranging behavior (e.g., Brockman and van Schaik, 2005).

Warm conditions and the potential for heat stress occurred less frequently than cool conditions, but appeared to evoke a stronger physiological response. Howlers' $T_{\mathrm{sc}}$ were tightly positively correlated with $T_{\mathrm{a}}$, yet showed a distinct plateau at $T_{\mathrm{a}}>41^{\circ} \mathrm{C}$, in which $T_{\mathrm{sc}}$ remained at $\sim 40.2^{\circ} \mathrm{C}$, despite increasingly warmer ambient conditions (Fig. 2). For comparison, human core body temperatures above $40^{\circ} \mathrm{C}$ are considered a criterion for heat stroke and can be associated with delirium, convulsions, and coma (Bouchama and Knochel, 2002). The reduced variation in howler $T_{\mathrm{sc}}$ at higher $T_{\mathrm{a}}$ (Fig. 2) suggests that animals are actively controlling their body temperature, while high variation in $T_{\mathrm{sc}}$ is indicative of flexible heat loss from the body at energetically neutral temperatures (Romanovsky et al., 2002). The mechanism for this cooling is unknown. Sweating appears to be important for some primate species (Stitt and Hardy, 1971; Johnson and Elizondo, 1979; Elizondo, 1988), although it does not occur to the extent seen in humans (Hanna and Brown, 1983). Howlers possess eccrine sweat glands on their palms and soles, glabrous portion of the tail, and throughout the hairy skin of the body (Montagna, 1972; Perkins, 1975), yet we have never observed visible sweating by howlers. Likewise, heat loss through panting is negligible in most primates (Elizondo, 1977, 1988) and we have never observed panting in howlers. Other common mammalian mechanisms to dissipate body heat include posture and microhabitat use, skin vasodilatation, decreased locomotor activity, and decreased energy intake (to reduce the heat generated by digestion) (Terrien et al., 2011). We predict that howlers are using many of these mechanisms, particularly extended (heat-dissipating) postures and selection of cool microhabitats to aid in thermoregulation. It is also likely that these commonly measured variables are being impacted by thermoregulation in a wide range of primate species, particularly those living in more extreme thermal environments. Our data imply that howlers experience warm thermal pressures, but that these events are acute and relatively infrequent while cool thermal pressures pose less intense physiological challenges, but are faced more often. The observation that primates in a dry tropical forest potentially experience both cool and warm thermal challenges suggests that thermoregulatory pressures may currently be underestimated for many tropical and midlatitude primates (Dausmann, 2014).

The maintenance of an optimal range of body temperature in the face of a changing thermal environment likely involves adjustments in many physiological and behavioral variables of interest to primate researchers. For instance, many mammals seasonally increase levels of the thyroid hormones triiodothyronine $\left(\mathrm{T}_{3}\right)$ and 
thyroxine $\left(\mathrm{T}_{4}\right)$ (Magdub et al., 1982; Tomasi, 1991). These hormones increase heat production by boosting basal metabolic rate and in turn lead to heightened food consumption and modifications in nutrient ingestion (Pijl et al., 2001; Silva, 2003; Silvestri et al., 2005). Thermoregulatory efforts may also impact short-term behavior including microhabitat choice, travel, activity budgets, and social contact. Given the prevalence of these variables in primatological studies and the dearth of body temperatures data from wild primates, we may be currently overlooking a key factor influencing physiology and behavior. An increased understanding of primate thermoregulation is needed to evaluate how thermal pressures impact the biology of free-ranging primates. This evaluation should consider simultaneously collected body and environmental temperatures, as well as additional thermal factors such as wind speed, humidity, precipitation, and solar radiation.

\section{ACKNOWLEDGMENTS}

The authors would like to thank Don Fernando Estrada and Hacienda La Pacifica's Board of Directors for their permission to conduct research on their land. They are also grateful to Francisco Campos, The Organization for Tropical Studies, and Ministerio del Ambiente y Energia (MINAE) for granting permits. They thank Dr. Walter Horne, DVM for providing animal welfare and surgical advice. Assistance in the field was given by: G. Alvarado, M. Clarke, P. Cofey, L. Corewyn, A. Doherty, T. Dolgushina, M. Ghandhi, A. Horner, M., Lattanzio, S. Mirhaidari, E. Naylor, E. Peiffer, N. Robl, C. Rose, J. Sidote, and K. Stover.

\section{LITERATURE CITED}

Agetsuma N. 1995. Dietary selection by Yakushima macaques (Macaca fuscata yakui): the influence of food availability and temperature. Int J Primatol 15:611-627.

Andersen KL, Hellström B. 1960. Oxygen intake and thermal balance in naked young men during rest and sleep at various ambient temperatures. Acta Physiol Scand 50:88-94.

Aujard F, Vasseur F. 2001. Effect of ambient temperature on the body temperature rhythm of male gray mouse lemurs (Microcebus murinus). Int J Primatol 22:43-56.

Baoping R, Ming L, Yongcheng L, Fuwen W. 2009. Influence of day length, ambient temperature, and seasonality on daily travel distance in the Yunnan snub-nosed monkey at Jinsichang, Yunnan, China. Am J Primatol 71:233-241.

Beehner JC, Onderdonk DA, Alberts SC, Altmann J. 2006. The ecology of conception and pregnancy failure in wild baboons. Behav Ecol 17:741-750.

Blanco MB, Rahalinarivo V. 2010. First direct evidence of hibernation in an eastern dwarf lemur species (Cheirogaleus crossleyi) from the high-altitude forest of Tsinjoarivo, centraleastern Madagascar. Naturwissenschaften 97:945-950.

Bouchama A, Knochel JP. 2002. Heat stroke. N Engl J Med 346:1978-1988.

Brain C, Mitchell D. 1999. Body temperature changes in freeranging baboons (Papio hamadryas ursinus) in the Namib desert, Namibia. Int J Primatol 20:585-598.

Brengelmann GL, Savage MV. 1997. Temperature regulation in the neutral zone. Ann N Y Acad Sci 813:39-50.

Brockman DK, van Schaik CP. 2005. Seasonality in primates: studies of living and extinct human and non-human primates. Cambridge University Press: New York.

Carrier DR, Kapoor AK, Kimura T, Nickels MK, Satwanti, Scott EC, So JK, Trinkaus E. 1984. The energetic paradox of human running and hominid evolution. Curr Anthropol 25: 483-495.
Chiarello AG. 1995. Grooming in brown howler monkeys, Alouatta fusca. Am J Primatol 35:73-81.

Cryan PM, Wolf BO. 2003. Sex differences in the thermoregulation and evaporative water loss of a heterothermic bat, Lasiurus cinereus, during its spring migration. J Exp Biol 206:3381-3390.

Daubenmire R. 1972. Phenology and other characteristics of tropical semi-deciduous forest in north-western Costa Rica. J Ecol 60:147-170.

Dausmann K. 2014. Flexible patterns in energy savings: heterothermy in primates. J Zool 292:101-111.

Dausmann K, Glos J, Heldmaier G. 2009. Energetics of tropical hibernation. J Comp Physiol B 179:345-357.

Dausmann KH. 2005. Measuring body temperature in the field-evaluation of external vs. implanted transmitters in a small mammal. J Therm Biol 30:195-202.

Dausmann KH, Glos J, Ganzhorn JU, Heldmaier G. 2004. Physiology: hibernation in a tropical primate. Nature 429: 825-826.

Dausmann KH, Glos J, Ganzhorn JU, Heldmaier G. 2005. Hibernation in the tropics: lessons from a primate. J Comp Physiol B 175:147-155.

Descamps S, Boutin S, Berteaux D, McAdam AG, Gaillard J. 2008. Cohort effects in red squirrels: the influence of density, food abundance and temperature on future survival and reproductive success. J Anim Ecol 77:305-314.

Di Fiore A, Link A, Campbell C. 2011. The atelines: Behavioral and socioecological diversity in a New World monkey radiation. In: Campbell CJ, Fuentes A, MacKinnon KC, Panger M, Beader SK, editors. Primates in Perspective, 2nd ed. Oxford: Oxford University Press. p 155-188.

Dunbar R. 1990. Environmental determinants of fecundity in klipspringer (Oreotragus oreotragus). Afr J Ecol 28:307-313.

Elizondo R. 1977. Temperature regulation in primates. Int Rev Physiol 15:71-118.

Elizondo RS. 1988. Primate models to study eccrine sweating. Am J Primatol 14:265-276.

Erikson H, Eirog J, Andersen KL, Scholander P. 1956. The critical temperature in naked man. Acta Physiol Scand 37:35-39.

Erkert H, Gröber J. 1986. Direct modulation of activity and body temperature of owl monkeys (Aotus lemurinus griseimembra) by low light intensities. Folia Primatol 47:171-188.

Erkert HG, Cramer B. 2006. Chronobiological background to cathemerality: circadian rhythms in Eulemur fulvus albifrons (Prosimii) and Aotus azarai boliviensis (Anthropoidea). Folia Primatol 77:87-103.

Fernandez-Duque E. 2003. Influences of moonlight, ambient temperature, and food availability on the diurnal and nocturnal activity of owl monkeys (Aotus azarai). Behav Ecol Sociobiol 54:431-440.

Folk GE, Semken HA. 1991. The evolution of sweat glands. Int J Biometeorol 35:180-186.

Fuller CA. 1984. Circadian brain and body temperature rhythms in the squirrel monkey. Am J Physiol-Reg I 246:R242-R246.

Fuller CA, Sulzman FM, Moore-Ede MC. 1985. Role of heat loss and heat production in generation of the circadian temperature rhythm of the squirrel monkey. Physiol Behav 34:543-546.

Geiser F, Holloway JC, Körtner G. 2007. Thermal biology, torpor and behaviour in sugar gliders: a laboratory-field comparison. J Comp Physiol B 177:495-501.

Genin F, Perret M. 2003. Daily hypothermia in captive grey mouse lemurs (Microcebus murinus): effects of photoperiod and food restriction. Comp Biochem Physiol B 136:71-81.

Glander KE. 1975. Habitat description and resource utilization: a preliminary report on mantled howling monkey ecology. In: Tuttle RH, editor. Socioecology and Psychology of Primates. The Hague: Mouton. p 37-57.

Glander KE. 2006. Average body weight for mantled howling monkeys (Alouatta palliata): An assessment of average values and variability. In: Estrada A, Garber PA, Pavelka M, Leucke $\mathrm{L}$, editors. New perspectives in the study of Mesoamerican primates. Springer: New York. p 247-263.

Glander KE, Fedigan LM, Fedigan L, Chapman C. 1991. Field methods for capture and measurement of three monkey species in Costa Rica. Folia Primatol 57:70-82. 
Glander KE, Nisbett RA. 1996. Community structure and species diversity in tropical forest associations at Hacienda La Pacifica in Guanacaste province, Costa Rica. Brenesia 45-46: 113-142.

Gordon CJ. 1990. Thermal biology of the laboratory rat. Physiol Behav 47:963-991.

Hanna JM, Brown DE. 1983. Human heat tolerance - an anthropological perspective. Annu Rev Anthropol 12:259-284.

Hansen PJ. 2009. Effects of heat stress on mammalian reproduction. Philos Trans R Soc Lond B 364:3341-3350.

Hanya G. 2004. Seasonal variations in the activity budget of Japanese macaques in the coniferous forest of Yakushima: effects of food and temperature. Am J Primatol 63:165-177.

Harrison M. 1985. Time budget of the green monkey, Cercopithecus sabaeus: some optimal strategies. Int J Primatol 6:351-376.

Hetem RS, Maloney SK, Fuller A, Meyer LC, Mitchell D. 2007. Validation of a biotelemetric technique, using ambulatory miniature black globe thermometers, to quantify thermoregulatory behaviour in ungulates. J Exp Zool A Ecol Genet Physiol 307:342-356.

Hiley P. 1976. The thermoregulatory responses of the galago (Galago crassicaudatus), the baboon (Papio cynocephalus) and the chimpanzee (Pan satyrus) to heat stress. J Physiol (Lond) 254:657-671.

Hill RA. 2006. Thermal constraints on activity scheduling and habitat choice in baboons. Am J Phys Anthropol 129:242-249.

Hill RA, Lycett JE, Dunbar RIM. 2000. Ecological and social determinants of birth intervals in baboons. Behav Ecol 11 $560-564$.

Hoban TM, Levine AH, Shane RB, Sulzman FM. 1985. Circadian rhythms of drinking and body temperature of the owl monkey (Aotus trivirgatus). Physiol Behav 34:513-518.

Holdridge LM. 1967. Life zone ecology. San Jose, Costa Rica: Tropical Science Center.

Honnebier M, Jenkins S, Nathanielsz P. 1992. Circadian timekeeping during pregnancy: endogenous phase relationships between maternal plasma hormones and the maternal body temperature rhythm in pregnant rhesus monkeys. Endocrinology 131:2051-2058.

Jablonski NG. 2004. The evolution of human skin and skin color. Annu Rev Anthropol 33:585-623.

Johnson GS, Elizondo RS. 1979. Thermoregulation in Macaca mulatta: a thermal balance study. J Appl Physiol 46:268-277.

Kenny GP, Journeay WS. 2010. Human thermoregulation: separating thermal and nonthermal effects on heat loss. Front Biosci 15:259-290.

Kobbe S, Dausmann KH. 2009. Hibernation in Malagasy mouse lemurs as a strategy to counter environmental challenge. Naturwissenschaften 96:1221-1227.

Kobbe S, Ganzhorn JU, Dausmann KH. 2011. Extreme individual flexibility of heterothermy in free-ranging Malagasy mouse lemurs (Microcebus griseorufus). J Comp Physiol B 181:165-173.

Le Maho Y, Goffart M, Rochas A, Felbabel H, Chatonnet J. 1981. Thermoregulation in the only nocturnal simian: the night monkey Aotus trivirgatus. Am J Physiol-Reg I 240: R156-R165.

Lopez KR, Gibbs PH, Reed DS. 2002. A comparison of body temperature changes due to the administration of ketamineacepromazine and tiletamine-zolazepam anesthetics in cynomolgus macaques. JAALAS 41:47-50.

Lovegrove B. 2009. Modification and miniaturization of Thermochron iButtons for surgical implantation into small animals. J Comp Physiol B 179:451-458.

Lovegrove BG, Canale C, Levesque D, Fluch G, Reháková-Petrů M, Ruf T. 2014. Are tropical small mammals physiologically vulnerable to arrhenius effects and climate change? Physiol Biochem Zool 87:30-45.

Lu S, Dai Y. 2009. Normal body temperature and the effects of age, sex, ambient temperature and body mass index on normal oral temperature: a prospective, comparative study. Int J Nurs Stud 46:661-668.

Mackowiak PA, Wasserman SS, Levine MM. 1992. A critical appraisal of $98.6^{\circ} \mathrm{F}$ the upper limit of the normal body tem- perature, and other legacies of Carl Reinhold August Wunderlich. JAMA 268:1578-1580.

Magdub A, Johnson HD, Belyea RL. 1982. Effect of environmental heat and dietary fiber on thyroid physiology of lactating cows. J Dairy Sci 65:2323-2331.

McMorris T, Swain J, Smith M, Corbett J, Delves S, Sale C, Harris RC, Potter J. 2006. Heat stress, plasma concentrations of adrenaline, noradrenaline, 5-hydroxytryptamine and cortisol, mood state and cognitive performance. Int J Psychophysiol 61:204-215.

McNab BK, Wright PC. 1987. Temperature regulation and oxygen consumption in the Philippine tarsier Tarsius syrichta. Physiol Zool 60:596-600.

Megahed G, Anwar M, Wasfy S, Hammadeh M. 2008. Influence of heat stress on the cortisol and oxidant-antioxidants balance during oestrous phase in buffalo-cows (Bubalus bubalis): thermo-protective role of antioxidant treatment. Reprod Domest Anim 43:672-677.

Milton K. 1998. Physiological ecology of howlers (Alouatta): Energetic and digestive considerations and comparison with the colobinae. Int J Primatol 19:513-548.

Milton K, Casey TM, Casey KK. 1979. The basal metabolism of mantled howler monkeys (Alouatta palliata). J Mammal 60: 373-376.

Mitchell D, Fuller A, Maloney SK. 2009. Homeothermy and primate bipedalism: is water shortage or solar radiation the main threat to baboon (Papio hamadryas) homeothermy? J Hum Evol 56:439-446.

Montagna W. 1972. The skin of nonhuman primates. Am Zool 12:109-124.

Müller EF. 1979. Energy metabolism, thermoregulation and water budget in the slow loris (Nycticebus coucang, Boddaert 1785). Comp Biochem Physiol A: Mol Integr Physiol 64:109119.

Mzilikazi N, Masters JC, Lovegrove BG. 2006. Lack of torpor in free-ranging southern lesser galagos, Galago moholi: ecological and physiological considerations. Folia Primatol 77:465476.

Nakayama T, Hori T, Nagasaka T, Tokura H, Tadaki E. 1971. Thermal and metabolic responses in the Japanese monkey at temperatures of 5-38 degrees C. J Appl Physiol 31:332-337.

Nowack J, Mzilikazi N, Dausmann KH. 2010. Torpor on demand: Heterothermy in the non-lemur primate Galago moholi. PloS One 5:e10797.

Nowack J, Wippich M, Mzilikazi N, Dausmann KH. 2013. Surviving the cold, dry period in Africa: behavioral adjustments as an alternative to heterothermy in the African lesser bushbaby (Galago moholi). Int J Primatol 34:49-64.

Nyakudya TT, Fuller A, Meyer LC, Maloney SK, Mitchell D. 2012. Body temperature and physical activity correlates of the menstrual cycle in chacma baboons (Papio hamadryas ursinus). Am J Primatol 74:1143-1153.

Ohsawa H, Dunbar RIM. 1984. Variations in the demographic structure and dynamics of gelada baboon populations. Behav Ecol Sociobiol 15:231-240.

Ortmann S, Heldmaier G, Schmid J, Ganzhorn J. 1997. Spontaneous daily torpor in Malagasy mouse lemurs. Naturwissenschaften 84:28-32.

Perkins EM Jr. 1975. Phylogenetic significance of the skin of New World monkeys (Order Primates, Infraorder Platyrrhini). Am J Phys Anthropol 42:395-423.

Perret M, Aujard F. 2001. Daily hypothermia and torpor in a tropical primate: synchronization by 24 -h light-dark cycle. Am J Physiol-Reg I 281:R1925-R1933.

Pijl H, de Meijer PHEM, Langius J, Coenegracht CIGM, van den Berk AHM, Chandie Shaw PK, Boom H, Schoemaker RC, Cohen AF, Burggraaf J, Meinders AE. 2001. Food choice in hyperthyroidism: potential influence of the autonomic nervous system and brain serotonin precursor availability. J Clin Endocrinol Metab 86:5848-5853.

Pörtner HO, Bennett AF, Bozinovic F, Clarke A, Lardies MA, Lucassen M, Pelster B, Schiemer F, Stillman JH. 2006. Trade-offs in thermal adaptation: the need for a molecular to ecological integration. Physiol Biochem Zool 79:295-313. 
Rasoloarison RM, Goodman SM, Ganzhorn JU. 2000. Taxonomic revision of mouse lemurs (Microcebus) in the western portions of Madagascar. Int J Primatol 21:963-1019.

Refinetti R. 2010. The circadian rhythm of body temperature. Front Biosci 15:564-594.

Refinetti R, Menaker M. 1992. The circadian rhythm of body temperature. Physiol Behav 51:613-637.

Robinson EL, Fuller CA. 1999. Light masking of circadian rhythms of heat production, heat loss, and body temperature in squirrel monkeys. Am J Physiol-Reg I 276:R298-R307.

Romanovsky AA, Ivanov AI, Shimansky YP. 2002. Selected contribution: ambient temperature for experiments in rats: a new method for determining the zone of thermal neutrality. J Appl Physiol 92:2667-2679.

Ross C. 1992. Basal metabolic rate, body weight and diet in primates: an evaluation of the evidence. Folia Primatol 58:7-23.

Schmid J. 2001. Daily torpor in free-ranging gray mouse lemurs (Microcebus murinus) in Madagascar. Int J Primatol 22:10211031.

Schmid J, Ruf T, Heldmaier G. 2000. Metabolism and temperature regulation during daily torpor in the smallest primate, the pygmy mouse lemur (Microcebus myoxinus) in Madagascar. J Comp Physiol B 170:59-68.

Schmid J, Speakman J. 2000. Daily energy expenditure of the grey mouse lemur (Microcebus murinus): a small primate that uses torpor. J Comp Physiol B 170:633-641.

Schmid J, Speakman J. 2009. Torpor and energetic consequences in free-ranging grey mouse lemurs (Microcebus murinus): a comparison of dry and wet forests. Naturwissenschaften 96 : 609-620.

Séguy M, Perret M. 2005. Factors affecting the daily rhythm of body temperature of captive mouse lemurs (Microcebus murinus). J Comp Physiol B 175:107-115.

Silva JE. 2003. The thermogenic effect of thyroid hormone and its clinical implications. Ann Intern Med 139:205-213.

Silvestri E, Schiavo L, Lombardi A, Goglia F. 2005. Thyroid hormones as molecular determinants of thermogenesis. Acta Physiol Scand 184:265-283.

Simpson S, Galbraith J. 1906. IV. Observations on the normal temperature of the monkey and its diurnal variation, and on the effect of changes in the daily routine on this variation. Trans R Soc Edinb 45:65-104.

Stitt JT, Hardy JD. 1971. Thermoregulation in the squirrel monkey (Saimiri sciureus). J Appl Physiol 31:48-54.
Takasu N, Nigi H, Tokura H. 2002. Effects of diurnal bright/ dim light intensity on circadian core temperature and activity rhythms in the Japanese macaque. Jpn J Physiol 52:573-578.

Tapp WN, Natelson BH. 1989. Circadian rhythms and patterns of performance before and after simulated jet lag. Am J Physiol-Reg I 257:R796-R803.

Terrien J, Perret M, Aujard F. 2011. Behavioral thermoregulation in mammals: A review. Front Biosci 16:1428-1444.

Tomasi TE. 1991. Utilization rates of thyroid hormones in mammals. Comp Biochem Physiol A Comp Physiol 100:503-516.

Vinyard C, Glander K, Teaford M, Thompson C, Deffenbaugh M, Williams S. 2012. Methods for studying the ecological physiology of feeding in free-ranging howlers (Alouatta palliata) at La Pacifica, Costa Rica. Int J Primatol 33:611-631.

Vuarin P, Dammhahn M, Henry P. 2013. Individual flexibility in energy saving: body size and condition constrain torpor use. Funct Ecol 27:792-799.

Warnecke L, Withers PC, Schleucher E, Maloney SK. 2007. Body temperature variation of free-ranging and captive southern brown bandicoots Isoodon obesulus (Marsupialia: Peramelidae). J Therm Biol 32:72-77.

Wang E, Milton K. 2003. Intragroup social relationships of male Alouatta palliata on Barro Colorado Island, Republic of Panama. Int J Primatol 24:1227-1243.

Webb P. 1992. Temperatures of skin, subcutaneous tissue, muscle and core in resting men in cold, comfortable and hot conditions. Eur J Appl Physiol Occup Physiol 64:471-476.

Whitford WG. 1976. Sweating responses in the chimpanzee (Pan troglodytes). Comp Biochem Physiol A Comp Physiol 53: 333-336.

Williams SH, Vinyard CJ, Glander KE, Deffenbaugh M, Teaford MF, Thompson CL. 2008. Telemetry system for assessing jawmuscle function in free-ranging primates. Int J Primatol 29: 1441-1453.

Winget CM, Card DH, Hetherington NW. 1968. Circadian oscillations of deep-body temperature and heart rate in a primate (Cebus albafrons). Aerosp Med 39:350-353.

Wyss CR, Rowell LB. 1976. Lack of humanlike active vasodilation in skin of heat-stressed baboons. J Appl Physiol 41:528-531.

Zihlman A, Cohn B. 1988. The adaptive response of human skin to the savanna. Hum Evol 3:397-409.

Zucker EL, Clarke MR. 1998. Agonistic and affiliative relationships of adult female howlers (Alouatta palliata) in Costa Rica over a 4-year period. Int J Primatol 19:433-449. 


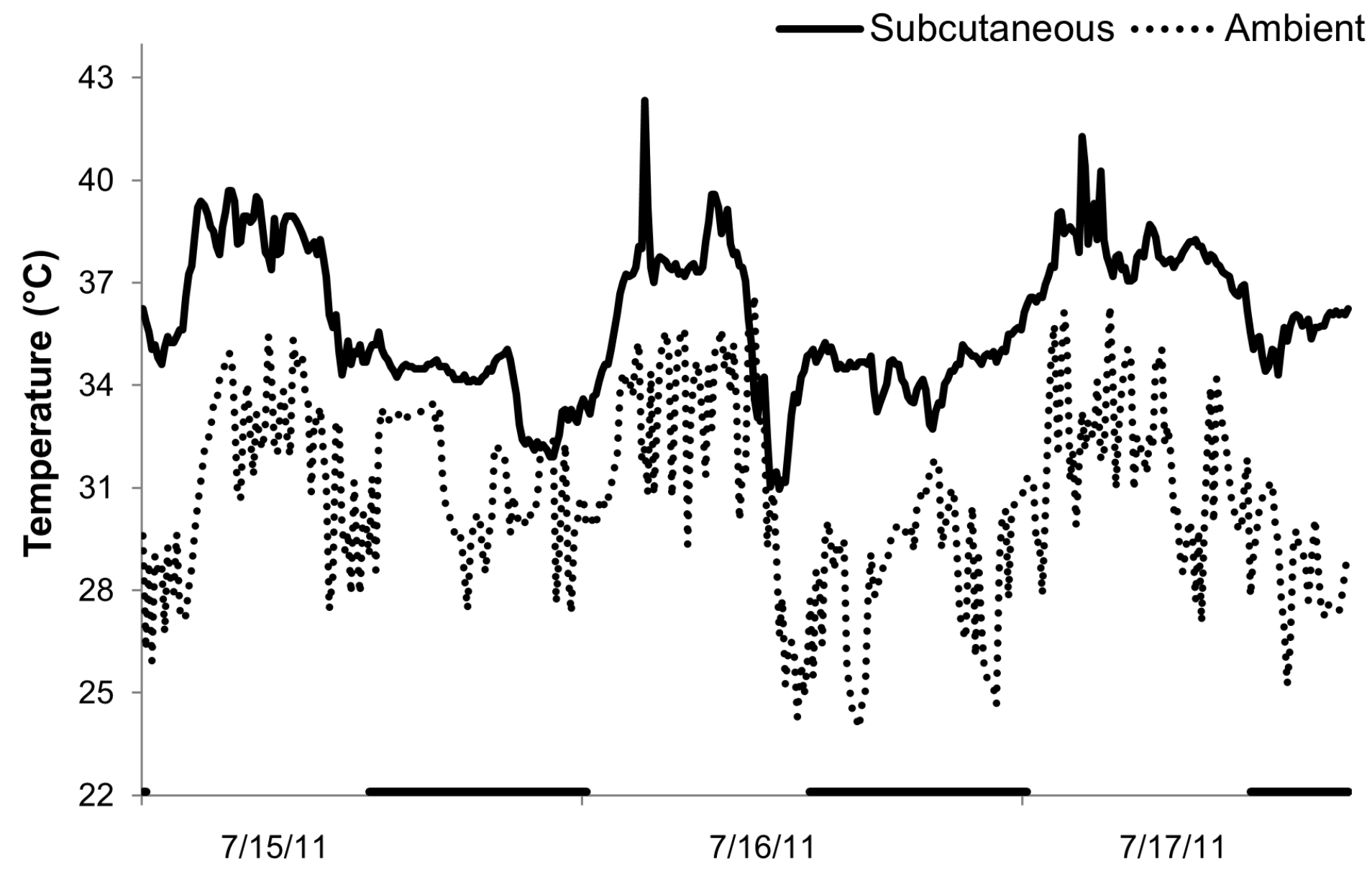

